\title{
WSCHODNI SĄSIEDZI POLSKI A BEZPIECZEŃSTWO EUROPY W MYŚLI POLITYCZNEJ JULIUSZA MIEROSZEWSKIEGO
}

\begin{abstract}
Artykuł ten jest próbą ujęcia poglądów Juliusza Mieroszewskiego, jednego z najbardziej wpływowych publicystów paryskiej „Kultury”, na rolę Ukrainy, Litwy, Białorusi i Rosji w kwestii bezpieczeństwa Polski i Europy. Publicysta ten wielokrotnie odnosił się do tego tematu na łamach paryskiej „Kultury” przedstawiając różne koncepcje działań, które jego zdaniem przyniosłyby najlepsze rezultaty. Mieroszewski uwzględniał rolę narodów ukraińskiego, litewskiego i białoruskiego w kształtowaniu przyszłości Polski, pomimo znajdowania się zamieszkiwanych przez nie terenów w granicach Związku Radzieckiego. Ważnym elementem publicystyki Mieroszewskiego było postulowanie konieczności współpracy pomiędzy Polską, Ukrainą, Litwą i Białorusią w budowaniu partnerskich relacji z Rosją. Publicysta „Kultury” podkreślał konieczność wielostronnej współpracy, tak na niwie realnej polityki, jak i kultury. Godne podkreślenia są przemyślenia dotyczące działań umożliwiających pojednanie między narodem polskim, a litewskim, ukraińskim i białoruskim. Autor artykułu próbuje uwypuklić innowacyjność i pragmatyzm w publicystyce Juliusza Mieroszewskiego opartej na realistycznej wizji polityki i stosunków międzypaństwowych przy uwzględnieniu zmienności w realiach środowiska międzynarodowego. Innym celem autora było pokazanie ewolucji koncepcji, w szczególności tych, które dotyczyły Związku Radzieckiego, gdyż zmienność układu sił i wewnętrzne napięcia w bloku wschodnim wymuszało niejednokrotnie rewizję uprzednich stwierdzeń. Autor próbował ukazać kompleksowość myśli politycznej paryskiej „Kultury” w wyżej wymienionych kwestiach, oraz pokazać oparcie prognoz i twierdzeń na kompleksowej znajomości realiów i społeczeństw, których predykcje te dotyczyły. Autor chciał pokazać, że Mieroszewski potrafił także przyznać się do popełnionych błędów i przewartościować koncepcje zgodnie z aktualnym zapotrzebowaniem. Ponadto uwypuklona została ponadczasowość niektórych spostrzeżeń Juliusza Mieroszewskiego, znajdujących zastosowanie nawet dzisiaj, szczególnie w kontekście ostatnich wydarzeń na Ukrainie.

Słowa kluczowe: bezpieczeństwo, paryska „Kultura”, wschodni sąsiedzi Polski, Juliusz Mieroszewski.
\end{abstract}

\section{WPROWADZENIE}

Juliusz Mieroszewski był jednym z najbardziej zasłużonych polskich pisarzy politycznych i publicystów, tworzących na emigracji po II wojnie światowej. Krzysztof Pomian zaliczył go do najoryginalniejszych twórców myśli politycznej w Europie Środkowo-Wschodniej. Na potwierdzenie tej tezy przywołał jego poglądy na demokrację jako wartość samą w sobie oraz realistyczne formułowanie celów w polityce ${ }^{2}$.

\footnotetext{
${ }^{1}$ Mgr Andrzej Janociński, UMCS w Lublinie, Plac Litewski 3, 20 - 080 Lublin, e-mail: andrzejjanocinski@interia.pl

${ }^{2}$ K. Pomian, Aktualność Mieroszewskiego, [w:] J. Giedroyc, J. Mieroszewski, Listy 1949-1956, oprac. K. Pomian, J. Krawczyk, Czytelnik, Warszawa 1999, s. 36.
} 
Juliusz Mieroszewski był jednym z publicystów paryskiej „Kultury”. Zadebiutował na jej łamach w 1949 roku, a stałą współpracę z periodykiem rozpoczął w roku następnym i kontynuował aż do śmierci. Zamieścił tam ponad 450 artykułów. To właśnie pod jego piórem dojrzewała i ewoluowała przez lata myśl polityczna paryskiej „Kultury”, szczególnie ta część dotycząca stosunków Polski z sąsiadami oraz prognoz rozwoju sytuacji międzynarodowej. Janusz Korek, badacz problematyki, przedstawił Mieroszewskiego jako naczelnego publicystę i tytułował go jako osobę numer dwa w „niewidzialnej redakcji” miesięcznika ${ }^{3}$. Nie było to stwierdzenie przesadzone, zważywszy na obfity dorobek publicystyczny, kreowanie linii politycznej pisma i pomysły natury organizacyjnej przedstawiane Jerzemu Giedroyciowi, redaktorowi naczelnemu, droga korespondencyjna.

Wkład Juliusza Mieroszewskiego w tworzenie politycznego wizerunku czasopisma i jego oficjalnej linii był nie do przecenienia. Od momentu wejścia w skład stałych współpracowników miesięcznika w 1950 r. stał się jednym z najważniejszych przedstawicieli tak zwanej opcji amerykańskiej, czyli koncepcji zakładającej rozwój Europy i wyzwolenie spod wpływów ZSRR państw komunistycznych za pomocą Stanów Zjednoczonych Ameryki. Koncepcja ta utrzymywała się jako główna aż do roku 1956 i zawierała $\mathrm{w}$ sobie przeświadczenie o nieuniknionej zbrojnej konfrontacji pomiędzy supermocarstwami i pomysły stworzenia federacji państw Europy Środkowo-Wschodniej. Aktywność publicystyczna Juliusza Mieroszewskiego obejmowała znacznie szerszą problematykę niż tylko sprawy związane z ZSRR i europejskimi państwami komunistycznymi - można znaleźć u niego postulaty normalizacji stosunków z Niemcami (już w 1951 r. zakładał ich nieuniknione zjednoczenie) ${ }^{4}$, a także prognozy stawiające ten kraj jako najsilniejszy w regionie, a co za tym idzie - jedyną alternatywę zjednoczeniową w wypadku wycofania się Amerykanów z Europy ${ }^{5}$.

Od roku 1955 w artykułach Mieroszewskiego można zauważyć swoistą dwoistość - z jednej strony ciagle była tam obecna opcja amerykańska, choć bez tak charakterystycznej dla lat wcześniejszych ufności w pomoc USA i zbrojną konfrontację supermocarstw, z drugiej strony współtworzenie linii, którą Janusz Korek nazwał „orientacją wschodnią” czy nawet opcją rosyjską ${ }^{6}$. Polegała ona na ułożeniu jak najlepszych stosunków z Rosją w trosce o interesy Polski jako państwa ${ }^{7}$. Do tego dodać należy teksty o polityce Polski Ludowej i kierunkach, w jakich powinni, zdaniem Mieroszewskiego, podażać decydenci komunistyczni ${ }^{8}$. Mieroszewski tworzył różne koncepcje funkcjonujące równocześnie, by zagospodarować każdą możliwość politycznego myślenia i działania, czym dawał powód do licznych polemik. Współtworzył i wzbogacał program wschodni czasopisma, sprowadzający się nie tylko do projektów o zasięgu krajowym, lecz także w szerszym kontekście europejskim, dostosowując je do zmieniającej się rzeczywistości politycznej na świecie.

\footnotetext{
${ }^{3}$ J. Korek, Paradoksy paryskiej „,Kultury”, Wydawnictwo UMCS, Lublin 2000, s. 25.

${ }^{4}$ J. Mieroszewski, List z Wyspy, „Kultura” 2-3/41-42 (1951), s. 7.

5Idem, O reformę „Zakonu Polskości”, „Kultura” 4/54 (1952), s. 10.

${ }^{6}$ J. Korek, op. cit., s. 252.

${ }^{7}$ J. Mieroszewski, Kwestia rosyjska, „Kultura” 11/109 (1956), s. 98.

${ }^{8}$ Idem, Karty na stót, „Kultura” 1/99 (1956), s. 3.
} 


\section{WSCHODNI SĄSIEDZI POLSKI}

Juliusz Mieroszewski uważał, że obszar Europy Środkowo-Wschodniej miał bardzo ważne znaczenie dla bezpieczeństwa Europy i całego świata. O tym przekonaniu zadecydowała jedna przesłanka: ranga kontynentu. Trwały pokój na świecie, a co za tym idzie - i w Europie, Mieroszewski uzależnił od dwóch czynników:

1. Utrzymaniu pokoju na „starym kontynencie”; służyć temu miało zjednoczenie Zachodniej i Wschodniej Europy.

2. Warunkiem realizacji tego postulatu było wyzwolenie państw środkowoeuropejskich spod dominacji ZSRR i demokratyzacja całego regionu.

Pokój i stabilność Europy i świata były najważniejszym zagadnieniem w rozważaniach nad bezpieczeństwem Polski i jej obywateli. Postęp technologiczny w dziedzinie zbrojeń sprawił, że następna wojna światowa mogłaby przynieść kres cywilizacji. Przy takim założeniu nie mogło być mowy o rywalizacji potęg na arenie międzynarodowej za pomocą wojny bezpośredniej. Rywalizacja musiała się przenieść na inne obszary. Przetrwanie małych państw w systemie dwubiegunowym zależało od prowadzenia stosownej polityki i dyplomacji, o ile mogły one sobie pozwolić na niezależność. Nic więc dziwnego, że relacje $\mathrm{z}$ sąsiadami stanowiły istotny element refleksji politycznej czasów „zimnej wojny”. Mieroszewski był przekonany, że ten obszar Europy jest kluczowy w utrzymaniu równowagi i pokoju na świecie. Za nieuniknione uważał zjednoczenie Niemiec i wyzwolenie od Związu Radzieckiego jego państw satelickich. Nie było to jednak łatwe.

Publicystyka dotycząca narodów i konieczności powstania w przyszłości, niepodległych państw Ukrainy, Litwy i Białorusi zajmowała ważne miejsce w myśli politycznej „Kultury”, a co za tym idzie - także Juliusza Mieroszewskiego. Koncepcje w kwestii państwa ukraińskiego, litewskiego czy białoruskiego, które można zaobserwować w „Kulturze”, a także w tekstach Mieroszewskiego, już na początku lat pięćdziesiątych, były częścią większej całości. Były zawsze powiązane $\mathrm{z}$ myśleniem $\mathrm{w}$ kategoriach europejskich, a nawet światowych. Na początku widać wyraźnie powiązanie z planami tworzenia federacji państw mającej stanowić przeciwwage dla Rosji i filar przyszłego bezpieczeństwa Polski. Wraz z odejściem od tak dalekosiężnego myślenia koncepcja zaczęła funkcjonować $w$ ramach pomysłu stworzenia neutralnego pasa pomiędzy Niemcami a Rosją, która pojawiła się w latach sześćdziesiątych. W obu wypadkach wyraźnie widoczna była obawa o kształt stosunków pomiędzy państwami Europy Wschodniej po rozpadzie sowieckiej strefy wpływów, gdyż bez wspólnego wroga ZSRR - do głosu dojść mogły odwieczne i skrywane do tej pory urazy. Z biegiem czasu polityka wobec aspirujących do niepodległości sąsiadów Polski zaczęła stanowić w publicystyce Mieroszewskiego część propozycji innego spojrzenia na Rosję. Za kluczową sprawę w ramach polskiej polityki wschodniej uważał on rzeczowe i spójne podejście do kwestii ukraińskiej. W tej sprawie publicysta miał naturalne wsparcie w „Kulturze”, która już na początku lat pięćdziesiątych, na długo przed pojawieniem się widma rozpadu systemu komunistycznego, zainicjowała działania na rzecz pojednania polskoukraińskiego ${ }^{9}$.

\footnotetext{
${ }^{9}$ Chodziło tu o stworzenie rubryki pod tytułem „Kronika ukraińska” oraz ukazywanie się artykułów związanych z tą tematyka, takich jak J. Tokarski, Co nas dzieli?, „Kultura” 5/55 (1952), s. 48; B. Lewyckyj, Ukraińcy a likwidacja Powstania Warszawskiego, „Kultura” 6/56 (1952), s. 39; W. Bączkowski, Sprawa Ukraińska, „Kultura”, nr 7-8/57-58 (1952), s. 68.
} 
Prawdopodobnie spośród wszystkich kwestii poruszanych w kontekście Polski i jej wschodnich sąsiadów najbardziej delikatną pozostawała sprawa granic i ich przesunięć. Po II wojnie światowej kształt terytorium państwa polskiego znacznie się zmienił. Polska utraciła dużą część ziem będących w jej granicach jeszcze w dwudziestoleciu międzywojennym. Ziemie te weszły w skład ZSRR, czego środowiska emigracyjne nigdy nie zapomniały i w żadnym wypadku nie mogły zaakceptować. Kwestia wschodnia była znamienna dla postawy i swoistej ewolucji myślenia Juliusza Mieroszewskiego, ukazując w pełni jego umiejętności wychodzenia poza kanony i powszechne stereotypy. Niedługo po wojnie, mimo trwającej już wówczas dyskusji polsko-ukraińskiej, nie zdradzał zainteresowania tym tematem, a także pośrednio opowiedział się za przedwojennym kształtem granic Polski ${ }^{10}$. Kwestionował wtedy twierdzenie Lewisa Namiera, angielskiego historyka i polityka, że traktat ryski oznaczał ni mniej, ni więcej, tylko rozbiór Białorusi i Ukrainy, choć później wraz ze zmianą swojej optyki w tej sprawie przyjął je na własność, zwracając uwagę na liczne podobieństwa między Rygą a Jałtą.

Prawdziwy problem pojawiał się $\mathrm{w}$ perspektywie możliwości tworzenia się państwowości na terenach zamieszkałych przez Ukraińców, Litwinów i Białorusinów. Rosnąca tam świadomość narodowa wskazywała na możliwość powstania niepodległych państw, jeśli doszłoby do rozpadu Związku Radzieckiego. Przerzucałoby to ewentualne roszczenia terytorialne $\mathrm{z}$ Rosji, odpowiedzialnej za przesunięcia graniczne na nowo powstałe byty polityczne. Nie bez znaczenia pozostawało istnienie historycznie umotywowanych animozji pomiędzy mieszkańcami tych obszarów a Polakami, uważanymi tam za naród ciemiężycieli. Taki stan rzeczy był nie do zaakceptowania, zważywszy na położenie geopolityczne Polski, Ukrainy, Litwy i Białorusi pomiędzy dwoma regionalnymi mocarstwami, to jest pomiędzy Rosją a Niemcami. Aby narody znajdujące się w takim sąsiedztwie mogły liczyć na pokój i przetrwanie, konieczne stawało się nawiązywanie pomiędzy nimi bliskiej współpracy, co z zasady wykluczało podtrzymywanie resentymentów czy nieufności. Jedyną możliwością osiągnięcia takiego stanu było zaakceptowanie ustalonej po II wojnie światowej granicy Polski.

Środowiska polskiej emigracji, w szczególności wywodzące się z dawnych kresów, często postulowały powrót Wilna i Lwowa w granice Rzeczpospolitej, bez należytego zrozumienia konsekwencji tych roszczeń. Zdecydowana większość emigracji (ok. 75\%, w dużej części pochodzącej z ziem wschodnich) opowiadała się za powrotem do wschodniej granicy Polski, wedle stanu sprzed wybuchu II wojny światowej. Ten typ myślenia można więc poczytać za normę w środowiskach emigracyjnych. Przykładem mogło być stanowisko Stanisława Paprockiego, specjalisty od kwestii wschodnich. Twierdził on, że polsko-ukraiński spór terytorialny nie mógł być rozwiązany przy zastosowaniu kryterium etnograficznego, gdyż przeczyły temu argumenty zarówno natury prawnej, historycznej, jak i politycznej. Paprocki uznawał jednak, że porozumienie polsko-ukraińskie było koniecznym nakazem polskiej racji stanu i ,aktualnej naszej polityki niepodległościowej" ${ }^{\prime 1}$.

Istnieli także publicyści, którzy twierdzili, że jakiekolwiek polskie działania na rzecz budowy niepodległej Ukrainy były niewłaściwe, niezrozumiałe, a nawet szkodliwe. U Jędrzeja Giertycha stanowisko takie brało się z przekonania, że niepodległa Ukraina stanie się sojuszniczką Niemiec i bardziej nawet niż Rosja będzie zagrażać kresom południowo-

\footnotetext{
${ }^{10}$ J. Mieroszewski, Historia powszechna milknie, „Wiadomości” 2/197 (1950), s. 74.

${ }^{11}$ S. Paprocki, Kwestia ukraińska, Londyn 1949, s. 32-33.
} 
wschodnim Rzeczpospolitej ${ }^{12}$. Innym przedstawicielem tego nurtu był Wacław Zbyszewski, bagatelizujący kwestię ukraińską, gdyż jego zdaniem była bez znaczenia wobec problemu fundamentalnego, czyli stosunków polsko-niemieckich. Przyrównywał wręcz zajmowanie się tą tematyką do zachowania człowieka, który zapomniawszy, że jest chory na raka, martwi się postępami kataru. W jego ocenie sprawa nie była warta zachodu $^{13}$

Według większości emigracji kwestia ukraińska była typowym przykładem problemu nierozwiązywalnego, przynajmniej dla tych, którzy niechętnie podchodzili do jakiejkolwiek formy kompromisu. Ten sposób myślenia triumfował, gdyż brakowało możliwości pogodzenia argumentu o integralności terytorialnej Rzeczpospolitej, przynajmniej w dawnych jej granicach, z tezą o konieczności porozumienia i pójścia na kompromis z Ukraińcami. Stwierdzić można, że w kwestii terytorium Polski emigracja okazała się niekonsekwentna, opowiadając się jednocześnie za granicą wschodnią wedle traktatu ryskiego i uznaniem za konieczne utrzymanie zachodniej granicy na Odrze i Nysie. Stanowisko takie świadczyło nie tylko o częściowej akceptacji Jałty, mimo że oficjalnie głoszono jej bezwzględne odrzucenie, ale było też dowodem relatywizmu w traktowaniu pojęcia kompensaty za straty wojenne. Polsce, według takiej wykładni i zgodnie ze sprawiedliwością dziejową, należały się ziemie zachodnie mimo niewielkiej obecności na nich żywiołu polskiego przed rokiem 1939. Ukraińcom natomiast nie należały się wschodnie ziemie Rzeczpospolitej, choć na znaczącej ich części stanowili etniczną większość.

Mieroszewski dawał wyraz przekonaniu, że w kwestii ustalenia granic istniały dwa logiczne stanowiska: albo granice sprzed roku 1939, albo z roku 1945. Koncepcje łączenia wschodniej granicy II RP z zachodnią z czasów Polski Ludowej uznawał za brak odpowiedzialności i patrzenia w przyszłość, gdyż pomysł taki dawał argumenty niemieckim rewizjonistom, chcącym przywrócenia swojej granicy wschodniej do stanu sprzed wojny ${ }^{14}$.

Mieroszewski nie był jedynym publicysta dostrzegającym konieczność dążenia do pojednania z Ukraińcami przez kompromis terytorialny, a przynajmniej pod względem rozpoczęcia tego procesu. Nie był także jedynym myślącym o polskiej granicy na wschodzie nie jako o granicy ze Związkiem Sowieckim, lecz z państwami będącymi tylko czasowo w jego obrębie, czyli Ukrainą, Litwą i Białorusią. To przede wszystkim za sprawą publicystyki Mieroszewskiego paryska „Kultura” rozpoczęła kampanię na rzecz wzbudzenia zainteresowania europejskim wschodem. Mieroszewski miał też niewątpliwą zasługę w obalaniu przekonania identyfikującego przedwojenny kształt Polski $\mathrm{Z}$ niepodległością. Wbrew temu, co myślało wielu Polaków i co już podczas wojny pisano o kresach $^{15}$, nie widział $\mathrm{w}$ nich nieodłącznego atrybutu niepodległości, a nawet starał się dowieść, że Polska bez ziem wschodnich będzie nawet bardziej spójna, suwerenna i niepodległa niż II Rzeczpospolita. Pogląd ten nie spotykał się wśród Polaków na emigracji ze szczególnie dobrym przyjęciem. Przeciwnie, w wielu środowiskach dawano do zrozumienia, że idea „Polski jagiellońskiej” była ciągle żywa. O ile czasy XVI i XVII wieku były interpretowane przez Polaków jako złoty okres rozkwitu państwa, o tyle przez

\footnotetext{
${ }^{12}$ J. Giertych, Sprawa Ukrainy a Polska, „Wiadomości” 34/282 (1951), s. 73.

${ }^{13}$ W.A. Zbyszewski, Polscy ukrainofile, „Wiadomości” 28/328 (1952), s. 28.

${ }^{14}$ J. Mieroszewski, Kronika angielska: Granice, „Kultura” 9/155 (1960), s. 63.

${ }^{15}$ K. Pruszyński, Wobec Rosji, ,Wiadomości Polskie” 40/134 (1942), s. 14.
} 
Ukraińców, Litwinów i Białorusinów, a nawet Rosjan określane były jako szczyt polskiego imperializmu, którego powrotu się obawiano.

Juliusz Mieroszewski nie bał się konfrontacji z nieprzychylnymi opiniami „kresowej” części emigracji, przedstawiając w swoich pismach realistyczne i zdroworozsądkowe wyjście z sytuacji i podkreślając brak możliwości powrotu do dawnych granic. Wyjaśniał, że rolą emigracji nie było ustalania granic, lecz zniwelowanie obaw przed rzekomym powrotem polskiego imperializmu. Tego typu jednoznaczne stanowisko spotykało się z krytyką rodaków, zdarzały się też oskarżenia pod adresem Mieroszewskiego o brak patriotyzmu. Takie stwierdzenia były wynikiem braku zrozumienia jego wieloaspektowego myślenia w dziedzinie polityki.

Budowanie porozumienia polsko-ukraińskiego, nawet jeśli odbywało się nie w kraju, a na obczyźnie, było dla Mieroszewskiego i „Kultury” warunkiem nieodzownym dla jakości współistnienia obu wielkich narodów w wolnej od komunizmu Europie. Alternatywę mogło stanowić jedynie powtórzenie tragicznej przeszłości naznaczonej walką pomiędzy Polakami a Ukraińcami, spotkanie z nimi „na moście w Przemyślu z karabinami w rękach"16.

O tym, że polityka pojednania pomiędzy Polską a państwami (wtedy jedynie narodami) oddzielającymi ją od Rosji była ważna, nikt nie musiał przekonywać publicystów „Kultury”. Uwypuklenie Ukrainy wynikało z jej potencjalnej siły - większe terytorium oraz liczba ludności niż Litwy i Białorusi razem wziętych. To, co postulował Mieroszewski, było nie tylko proste, ale - co ważniejsze - logiczne. Wysuwająca pod adresem Ukrainy roszczenia rewindykacyjne, to znaczy żądająca oddania Lwowa, Polska mogłaby się jednocześnie przyczynić do zbliżenia ukraińsko-niemieckiego, aliansu dwóch państw dla Polski nie tylko skrajnie niekorzystnego, ale również zagrażającego jej bezpieczeństwu. Alians ukraińsko-niemiecki odtwarzałby bowiem układ otoczenia Rzeczpospolitej przez państwa nieprzyjazne i zmuszał Polskę do podjęcia ponownie, na wzór II RP, polityki lawirowania pomiędzy silnymi sąsiadami, nieskutecznej w 1939 r. Polska byłaby skazana przy takim układzie na klęskę, bo oznaczałby on izolację kraju na arenie międzynarodowej ${ }^{17}$. Uznając zaś granice z 1945 r. za nienaruszalne i ostateczne, Mieroszewski dowodził, że za sprawą Polski „ukraińska orientacja proniemiecka staje się absolutnie bezprzedmiotowa" 18 , łącząc przy okazji w jedno polską politykę wschodnią z zachodnia.

Podsumowując rozważania dotyczące wschodnich sąsiadów w myśli politycznej Mieroszewskiego, należy stwierdzić, że najwięcej uwagi poświęcono Ukrainie, Litwa i Białoruś zaś zajęły w niej znacznie mniej miejsca. W poglądach na wschodnią granicę Polski Mieroszewski miał rację. Trudno było sobie wyobrazić utrzymanie logiki i wewnętrznej spójności koncepcji polityki wschodniej, jeśli Lwów miał pozostać przy Ukrainie, a Wilno przy Polsce. Logika i spójność były dla publicysty „Kultury” sprawą pierwszoplanową. Co więcej, postulował on, aby nie tylko nie domagać się zwrotu tych miast, ale dodatkowo zapewniać, że „Polska nie sięgnie po nie zbrojnie, nawet jeśli będzie taka okazja,"19.

\footnotetext{
${ }^{16}$ J. Mieroszewski, List z Wyspy: Prywatne inicjatywy polityczne, „Kultura” 10/60 (1952), s. 32.

${ }^{17}$ Idem, Geoideologia, „Kultura” 12/206 (1964),s. 7.

${ }^{18}$ Idem, Polska “Ostpolitik”, „Kultura” 6/309 (1973), s. 76.

${ }^{19}$ Ibidem, s. 76.
} 


\section{GEOPOLITYCZNE ZNACZENIE EUROPY ŚRODKOWOWSCHODNIEJ}

Kwestia przezwyciężenia przeszłości i przyjazna współpraca z Ukrainą, Litwą i Białorusią miały szerszy kontekst. Postulowane przez Mieroszewskiego wspieranie demokratyzacji na Wschodzie nie wiązało się jedynie z misją cywilizacyjną czy przyświecającymi Polsce ideałami wolności. Popieranie dążeń niepodległościowych za wschodnią granicą wiązało się przede wszystkim z interesem państwa, zwanym inaczej racja stanu. Wedle Mieroszewskiego, triumf $w$ Europie Wschodniej, czyli realizacja polskich ambicji za tą granicą przez pociagnięcie narodów Ukrainy, Litwy i Białorusi w stronę demokratycznej części kontynentu, oznaczał równocześnie sukces w polityce sąsiedztwa z Niemcami. Mieroszewski wychodził z przekonania, że koniec imperium sowieckiego nie tylko otworzy możliwość demokratyzacji byłych państw satelickich, ale również umożliwi ponowne zjednoczenie Niemiec. Wobec potencjalnej siły sąsiada za Odrą porozumienia zawarte $\mathrm{z}$ państwami ościennymi na wschodzie będą stanowić najlepszą gwarancję niepodległości Polski i bezpieczeństwa jej obywateli. Nawet więcej, bo w ocenie Mieroszewskiego żaden z sojuszy zawartych na Zachodzie nie będzie równie istotny dla państw demokratycznych jak porozumienie z Ukrainą, Litwą czy Białorusią, które staną się w przyszłości wyznacznikiem siły państwa polskiego i wpływów, jakie Rzeczpospolita będzie miała na politykę europejską i szerzej - światową. Stosunki Polski z tymi państwami wiązały się dla Mieroszewskiego, w sposób niepodlegający dyskusji, z kwestią rosyjska.

Stosunek do Rosji podlegał ewolucji, niemniej Mieroszewski zawsze brał pod uwage wymienione państwa jako element ważny lub nawet kluczowy. W roku 1951 publicysta „Kultury” wiązał rację stanu z „,walką przeciw Sowietom na wszystkich dostępnych nam polach i w każdej dostępnej nam formie" ${ }^{, 20}$. Stąd brała się na przykład propozycja stworzenia, w czasie trwania wojny koreańskiej brygady wschodnioeuropejskiej ${ }^{21}$, by walkę z ZSRR przenieść także na grunt militarny. Ten punkt widzenia się zmienił, z czasem bowiem Mieroszewski zrozumiał, jak nikłe i nieskuteczne mogły się okazać przedsięwzięcia wymierzone w ZSRR. Zaczął także dostrzegać możliwość wewnętrznych przemian w imperium sowieckim, zmiany w sposobie funkcjonowania tego państwa, a w efekcie erozji systemu. Rozpad Związku Radzieckiego nie był jednak postrzegany jako koniec problemu rosyjskiego, ale raczej jako otwarcie nowego rozdziału w trudnych stosunkach z wielkim sąsiadem. Publicysta „Kultury” rozumiał, że żaden ustrój panujący w Rosji nie zniweczy zagrożenia. Warto przypomnieć, że podobnie myślał Józef Piłsudski, odmawiając pomocy „białym” podczas rewolucji, gdyż wiedział, że Rosja „biała” będzie równie lub nawet bardziej niebezpieczna niż „czerwona”.

W latach sześćdziesiątych $\mathrm{w}$ publicystyce Mieroszewskiego dało się zauważyć przekonanie, że bez względu na to, czy możliwe były do urzeczywistnienia plany federacji w Europie Środkowej, czy stworzenie pasa neutralnego pomiędzy Rosją a Niemcami, Polska musiała porozumieć się z którymś ze swoich wielkich sąsiadów, przełamując polityczny impas i niemoc trwającą od czasów I Rzeczpospolitej. Najważniejszym politycznym pytaniem, na które musiała odpowiedzieć niepodległa Polska, było: jak nie dopuścić do sojuszu Niemiec i Rosji, będącego już niejednokrotnie przyczyną klęski i upadku Rzeczpospolitej ${ }^{22}$. Według Mieroszewskiego niedopuszczalna

\footnotetext{
${ }^{20}$ Idem, List z Wyspy, „Kultura” 2-3/41-42 (1951), s. 89.

${ }^{21}$ Idem, O międzynarodowa brygadę europejskq „Kultura” 11/49 (1951), s. 81.

${ }^{22}$ J. Mieroszewski, Geoideologia..., s. 8.
} 
była sytuacja, by siła państwa polskiego opierała się w głównej mierze na słabości któregoś z regionalnych mocarstw, a niepodległość zależała od konfliktu między nimi. Nic nie zmazałoby widma tymczasowości suwerenności Polski. Kończyłaby się ona wraz z sojuszem Berlina i Moskwy.

W tej kwestii publicysta „Kultury” polemizował z wieloma autorami. Jednym z nich był Adolf Bocheński prezentujący proniemiecki kierunek orientacji geopolitycznej. Mieroszewski doceniał argumentację adwersarza, jednak się $z$ nią nie zgadzat ${ }^{23}$. „Londyńczyk” nie zdecydowałby się na powiązanie z Niemcami, mimo że uważał Rosję za zagrożenie, któremu należało zaradzić w pierwszej kolejności. Spór, jaki istniał między Polską a Rosją, miał charakter ideologiczny, polityczny i był wpisany niejako w szerszy kontekst sporu cywilizacyjnego między Wschodem i Zachodem ${ }^{24}$.

Warunkiem ułożenia poprawnych stosunków z Rosją było umocnienie wpływów i pozycji Polski na wschodzie, bo jedynie mocne usytuowanie w regionie dawało dobrą pozycję do rozmów mocarstwem. Tutaj ponownie widać było wyraźnie, że kluczem do sukcesu były państwa regionu. Mieroszewski uważał, że Rzeczpospolita przegrała polityczną grę na Wschodzie i swoją pozycję w regionie na długo przed upadkiem państwa. Interesujące było to, że powodem porażki w walce o wpływy była siła państwa, a nie jego słabość. „Brak mądrej i dalekowzrocznej polityki wschodniej”,25 spowodował, że dla Ukraińców, Litwinów, czy Białorusinów dominacja Polski w regionie była niczym innym jak imperializmem. Pretensje Rzeczpospolitej do odgrywania roli mocarstwa regionalnego nie zostały jednak poparte wystarczającą siłą militarną ani gospodarczą, ani dyplomatyczną, co pozwoliło na stały wzrost znaczenia Moskwy. W ostatecznym rozrachunku w momencie zderzenia imperializmu polskiego $\mathrm{z}$ rosyjskim wygrał ten silniejszy ${ }^{26}$.

Mieroszewski uważał, że traktat ryski, ustalający granicę pomiędzy Polską a Związkiem Radzieckim, ponad zainteresowanymi narodami, Ukraińcami, Litwinami czy Białorusinami, mógł stanowić swoiste preludium do uzgodnień w Jałcie, wykazujących taką samą mechanikę, jeśli chodzi o podejmowanie decyzji ${ }^{27}$. W dwudziestoleciu międzywojennym niemożliwe było prowadzenie polityki wschodniej z perspektywy mocarstwowej ze względu na wpływy ZSRR w regionie. Polsce pozostawało jedynie stworzenie szerokiej autonomii dla mniejszości narodowych, co ostatecznie nie nastapiło, przyczyniając się pośrednio do kolejnego upadku państwa polskiego. Traktat ryski był wynikiem nieudanych planów federacyjnych Piłsudskiego. Stanowił on konieczność z punktu widzenia polskiej racji stanu, jednak pewne porównania z ,Jałtą” były tutaj jak najbardziej na miejscu.

Lansowano przez stulecia wizerunek Polski jako ,przedmurza”, najdalej wysuniętego na wschód kraju łacińskiej (zachodniej) cywilizacji europejskiej. Jak zauważył to Mieroszewski, nacisk położono na to, co oddzielało i różniło Rzeczpospolitą i Polaków od narodów mieszkających na wschodzie. Takie ujęcie sprawy nie przybliżało do sojuszu z sąsiadami ze wschodu czy poprawnych stosunków politycznych z Rosją. Mieroszewski

\footnotetext{
${ }^{23}$ Idem, Tytut pozostaje ten sam, „Kultura” 12/242 (1967), s. 39.

${ }^{24}$ Idem, Geoideologia..., s. 7.

${ }^{25}$ Idem, Wstęp, [w:] idem, Dialog polsko-niemiecki w świetle dokumentów kościelnych, Paryż 1966, s. 10.

${ }^{26}$ Idem, Punkt odniesienia, „Kultura” 5/223 (1966), s. 34.

${ }^{27}$ Idem, Kronika angielska: Sklepy z opiniami, „Kultura” 3/89 (1955), s. 87.
} 
postulował odwrócenie tej optyki, zamieniając ,przedmurze” na „pomost”, stawiając Polsce zadanie „cywilizowania” czy „europeizowania” Rosji, do czego bez wsparcia narodów Ukrainy, Litwy i Białorusi było daleko. Projekt demokratyzacji Rosji Sowieckiej miał w wypadku sukcesu doprowadzić do pojednania polsko-rosyjskiego, a tym samym niepodległości Polski ${ }^{28}$, co z kolei skutkowałoby rozwiązaniem problemu sporów ze wschodnimi sąsiadami, gdyż przyjaźń polsko-rosyjska wyeliminowałaby odwieczną walkę o wpływy w regionie.

W celu sprostania wyzwaniom przyszłości należało bowiem zakończyć opieranie koncepcji państwa na rzekomym zadaniu odpierania wschodniego barbarzyństwa, a przekierować energię Polaków na znacznie istotniejszy z punktu widzenia Europy i świata cel, a mianowicie udział w ,przebudowie i zorganizowaniu europejskiego wschodu” ${ }^{29}$.

\section{ZAKOŃCZENIE}

Rozważania nad myślą polityczną Juliusza Mieroszewskiego pozwalają na sformułowanie trzech wniosków. Po pierwsze, postulaty Juliusza Mieroszewskiego okazały się bardzo aktualne. Zjednoczenie Niemiec nastapiło, zaraz po tym jak w Polsce system komunistyczny zaczął pękać. Demokratyzacja objęła państwa powstałe po rozpadzie Związku Radzieckiego. Pytaniem otwartym pozostaje, czy zakończyła się walka o demokratyczną Europę?

Po drugie, Rosja, zgodnie z przewidywaniami Mieroszewskiego, niezależnie od kształtu ustroju politycznego ciągle ma mocarstwowe dążenia w sposób naturalny ciążące ku rozszerzaniu strefy wpływów na zachód. Ukraina, Litwa, Białoruś i Polska pozostają w obszarze ścierania się interesów Rosji i Niemiec. Projekt pod nazwą Unia Europejska skłonił Polskę i Litwę do współpracy bardziej z Niemcami niż Rosją, podczas gdy Białoruś pozostaje nadal silnie związana $\mathrm{z}$ wielkim wschodnim sąsiadem. Najbardziej skomplikowana jest $w$ tym układzie pozycja Ukrainy. $Z$ jednej strony elity rządzące chcą utrzymywać intratną $\mathrm{z}$ ich punktu widzenia rolę pośrednika $\mathrm{w}$ relacjach UE-Rosja. Z drugiej strony społeczeństwo wykazuje wyraźne ciążenie $\mathrm{w}$ kierunku integracji $\mathrm{z}$ zachodem.

Po trzecie, za Mieroszewskim można powtórzyć, że polską racją stanu jest wspieranie każdej prodemokratycznej inicjatywy zmiany na Wschodzie. Wydaje się, że bardziej niż kiedykolwiek polskie społeczeństwo jest gotowe do budowania „,pomostu” łączącego demokratyczną Europę Zachodnią z postkomunistyczną Wschodnią. Dla bezpieczeństwa i przyszłości Polski najważniejsze jest wspieranie dążeń prozachodnich Ukraińców, gdyż tylko w ten sposób można przekonać ich o dobrych intencjach. Tak jak twierdził Mieroszewski, Rzeczpospolita jako mocarstwo już nie powróci. Jej miejsce może zająć silne suwerenne państwo polskie, budujące relacje z sąsiadami na zasadzie współpracy równoprawnych podmiotów. Tylko w tej roli Polska będzie bezpieczna i szanowana, a jej zdanie brane pod uwagę.

\section{LITERATURA:}

[1] Korek J., Paradoksy paryskiej „,Kultury”, Wydawnictwo UMCS, Lublin 2000.

[2] Mieroszewski J., Wstęp, [w:] idem, Dialog polsko-niemiecki w świetle dokumentów kościelnych, Paryż 1966.

\footnotetext{
${ }^{28}$ Idem, Ustrój - geopolityka - niepodległość, „Kultura” 11/229 (1966), s. 31.

${ }^{29}$ Idem, Tysiac lat i co dalej?, „Kultura” 7-8/225-226 (1966), s. 9.
} 
[3] Paprocki S., Kwestia ukraińska, Londyn 1949.

[4] Pomian K., Aktualność Mieroszewskiego, [w:] J. Giedroyc, J. Mieroszewski, Listy 1949-1956, , oprac. K. Pomian, J. Krawczyk, Czytelnik, Warszawa 1999.

[5] „Kultura” 1951-1967.

[6] „Wiadomości” 1950-1952.

[7] „Wiadomości Polskie” 1942.

\section{EASTERN NEIGHBORS OF POLAND AND THE SECURITY OF EUROPE IN POLITICAL THOUGHS OF JULIUS MIEROSZEWSKI}

This article is an attempt to approach the views of Julius Mieroszewski, one of the most influential journalists in Paris "Culture", on the role of Ukraine, Lithuania, Belarus and Russia for Polish and European security. This columnist has repeatedly referred to this subject in the pages of Paris "Culture" by presenting various concepts of operations, which he believes would deliver the best results. Mieroszewski takes into account the role of the nations of the Ukrainian, Lithuanian and Belarusian in shaping the future of Poland, despite the fact that areas populated by those nations were inside the borders of the Soviet Union. An important element of Mieroszewski's journalism is a fact that he has been advocating the need for cooperation between Poland, Ukraine, Lithuania and Belarus in building partnership relations with Russia. Publicist of "Culture" emphasized the need for multilateral cooperation, so on floodplain of real politics, and culture. There are highlighted the thoughts on actions for reconciliation between the Polish and Lithuanian, Ukrainian, Belarusian. The article attempts to show innovation and pragmatism in journalism of Julius Mieroszewski based on a realistic vision of politics and international relations, taking into account the variability in the realities of the international environment. Another aim of the author was to show the evolution of the concept, in particular those related to the Soviet Union, since the variation of forces and tensions within the Eastern bloc often necessitated revision of the previous statements. The author tried to show the complexity of the political thought of the Paris "Culture" in the above-mentioned issues, and to show support forecasts and statements on a comprehensive knowledge of the realities and societies, these predictions are concerned. The author wanted to show that Mieroszewski also able to admit mistakes and re-evaluate concepts according to the current demand. In addition, author want to show and emphasizes the timelessness of some observations of Julius Mieroszewski applicable even today, especially in the context of recent events in Ukraine. Keywords: security, Paris 'Culture', Polish eastern neighbors, Julius Mieroszewski.

DOI:10.7862/rz.2014.hss.21

Przesłano do redakcji: marzec 2014

Przyjęto do druku: lipiec 2014 